\title{
Minimally invasive parathyroidectomy using intraoperative ultrasonographic localization for primary hyperparathyroidism in pregnancy: report of two cases
}

\author{
Mehmet Haciyanlı ${ }^{1}$, Emine Özlem Gür ${ }^{1}$, Hüdai Genç ${ }^{1}$, Selda Gücek Haciyanlı ${ }^{1}$, Fatma Tatarr ${ }^{1}$, Turan Acar ${ }^{1}$, Serkan Karaisli ${ }^{1}$ \\ ${ }^{1}$ Clinic of General Surgery, Izmir Katip Celebi University Ataturk Training and Research Hospital, Izmir, Turkey
}

\begin{abstract}
Primary hyperparathyroidism (pHPT) in pregnancy is a rare entity associated with increased maternal and fetal mortality and morbidity. Diagnosis of pHPT is challenging in pregnancy. Approximately $80 \%$ of the cases are asymptomatic, while the most common symptoms are nausea, vomiting, polyuria, polydypsia, and cloudy vision in symptomatic patients. Since the most common cause of pHPT in pregnancy is adenoma, such in the general population, focused anterior or lateral approach is recommended due to shorter operation time, less risk for the fetus, and lower complication risk. Performing intraoperative ultrasonography to do the incision just over the adenoma provides quicker access to the adenoma and intraoperative parathormone assay confirms the surgical cure. Laryngeal mask anesthesia causes lesser sore throat, laryngospasm, coughing, and rapid recovery as compared to endotracheal intubation anesthesia. This study aimed to present the management of two pregnant patients diagnosed with pHPT and who underwent minimally invasive parathyroidectomy under intraoperative ultrasonography and laryngeal mask anesthesia at the second trimester of gestation. To the best of our knowledge, parathyroidectomy under laryngeal mask anesthesia in pregnancy has never been described before.
\end{abstract}

Keywords: Intraoperative ultrasonography, laryngeal mask anesthesia, minimally invasive parathyroidectomy, pregnancy, gestational hyperparathyroidism

Cite this article as: Haciyanli M, Gür EÖ, Genç H, Gücek Haciyanli S, Tatar F, Acar T, Karaisli S. Minimally invasive parathyroidectomy using intraoperative ultrasonographic localization for primary hyperparathyroidism in pregnancy: report of two cases. Turk J Surg 2019; 35 (3): 231-235.

\section{Corresponding Author} Serkan Karaisli

E-mail: skaraisli@hotmail.com

Received: 08.10.2018

Accepted: 08.01.2019

Available Online Date: 23.09.2019

O Copyright 2019 by Turkish Surgical Society Available online at www.turkjsurg.com

DOI: $10.5578 /$ turkjsurg.4330

\section{INTRODUCTION}

Primary hyperparathyroidism (pHPT) in pregnancy is a rare but serious entity associated with increased maternal and fetal mortality and morbidity. The exact incidence remains unclear due to asymptomatic cases and many similar symptoms are shared by hyperparathyroidism and pregnancy such as hyperemesis, vomiting, bone pain and fatigue (1). Nephrolithiasis, acute pancreatitis and rarely hypercalcemic crisis are the most serious complications for pregnant woman during intrauterine growth retardation, preterm labor and neonatal tetany for the fetus (2-4). Management of the pregnant women with hyperparathyroidism is also challenging, and maternal and fetal morbidity and mortality can be prevented with prompt treatment approaches.

This study aimed to present management of two pregnant patients who were diagnosed with pHPT and underwent minimally invasive parathyroidectomy under laryngeal mask anesthesia (LMA) in the second trimester of gestation.

\section{CASE REPORTS}

\section{Case 1}

A 25-year-old pregnant woman (G1P0) was admitted to hospital with a complaint of severe nausea and muscle cramp at the $19^{\text {th }}$ week of gestation. She had no history of any previous disease, operation, family history of chronic diseases and medication. Physical examination was insignificant. In initial laboratory tests, serum calcium level was $11.8 \mathrm{mg} / \mathrm{dL}$ (reference range = 8.5-10.5 mg/dL), phosphorus was $2 \mathrm{mg} / \mathrm{dL}$ (reference range $=2.5-4.5 \mathrm{mg} / \mathrm{dL}$ ) and albumin level was within normal limits. On additional tests, parathormone (PTH) level was found $192 \mathrm{pg} / \mathrm{mL}$ (reference range $=18-78$ $\mathrm{pg} / \mathrm{mL}$ ) and $24 \mathrm{~h}$ urinary calcium as $680 \mathrm{mg}$ (reference range $=100-150 \mathrm{mg}$ ). Neck 


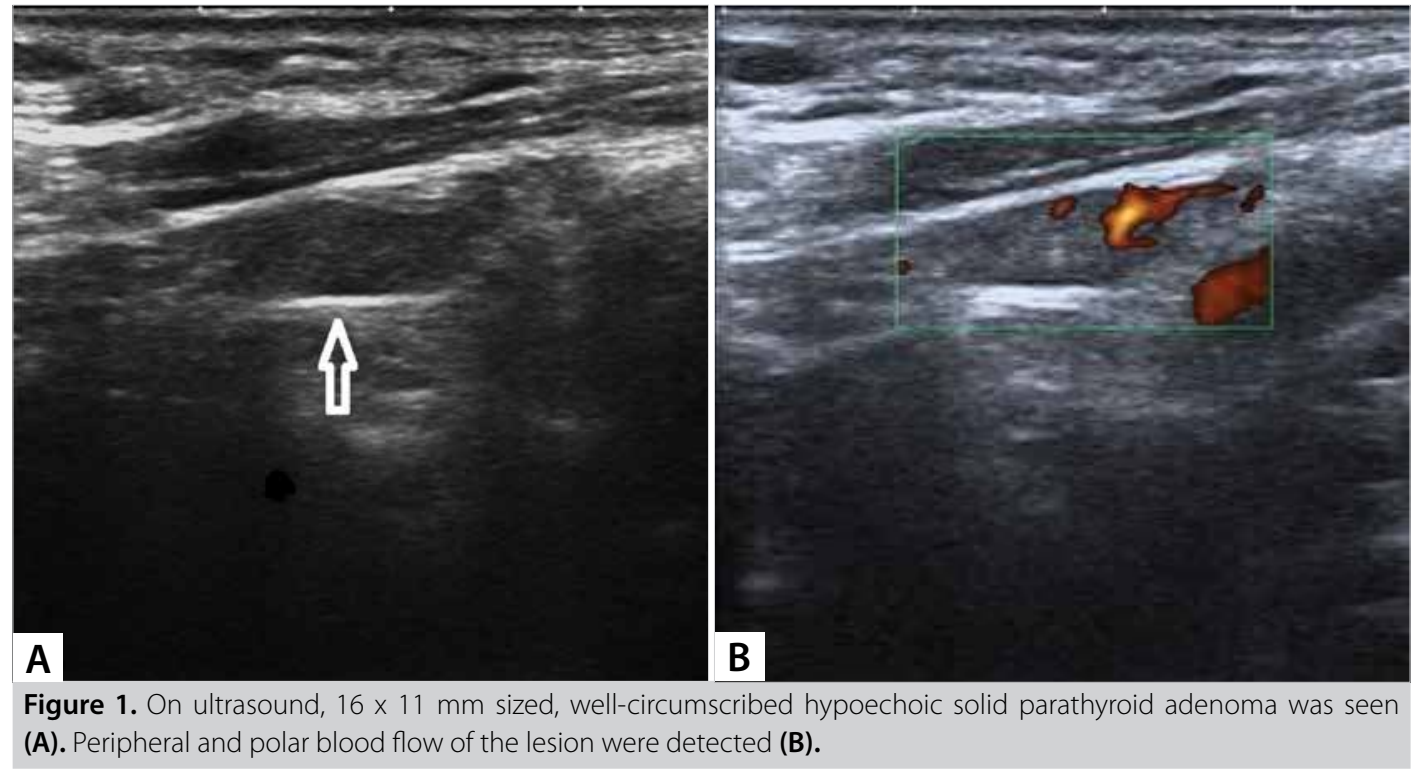

ultrasonography (USG) revealed a solitary left inferior parathyroid adenoma $1.6 \mathrm{~cm}$ in diameter (Figure 1). Surgery was recommended for the patient and risks of both the disease and operation were informed. After oral and intravenous rehydration without forced diuresis and an overnight fasting, the patient was operated under LMA. Intraoperative USG was used for prompt detection of the incision site just over the adenoma to prevent both the patient and the fetus from adverse effects of prolonged anesthesia. Focused lateral approach (FLA) was applied, and sufficient intraoperative PTH drop was achieved 10 minutes after excision of the adenoma (from $185 \mathrm{pg} / \mathrm{mL}$ to $56 \mathrm{pg} / \mathrm{mL}$ ).

Postoperative maternal and fetal health was well, and the patient was discharged 2 days after the operation with normal serum calcium and PTH levels. Histopathological examination confirmed the diagnosis of solitary parathyroid adenoma (Figure 2). At the $39^{\text {th }}$ week of gestation, she delivered a healthy male infant with no evidence of neonatal tetany or LMA related complication.

\section{Case 2}

A 36-year-old pregnant woman (G3P2) who was at the $24^{\text {th }}$ week of gestation was referred to our department due to elevated serum calcium level which was detected in regular outpatient visit. The patient denied any history of previous disease, operation and family history of chronic diseases. Physical examination was unremarkable. Laboratory tests revealed hypercalcemia with a serum calcium level of $12.4 \mathrm{mg} / \mathrm{dL}$ (reference range $=8.5-10.5 \mathrm{mg} / \mathrm{dL}$ ) and phosphorus of $2.3 \mathrm{mg} / \mathrm{dL}$ (reference range= $2.5-4.5 \mathrm{mg} / \mathrm{dL}$ ). PTH level was found as $286 \mathrm{pg} / \mathrm{mL}$ (reference range $=18-78 \mathrm{pg}$ / $\mathrm{mL}$ ) and $24 \mathrm{~h}$ urinary calcium as $340 \mathrm{mg}$ (reference range $=100$ $150 \mathrm{mg}$ ). Neck USG showed a solitary parathyroid adenoma 2.1 $\mathrm{cm}$ in diameter at the inferior margin of the right thyroid lobe (Figure 3). After oral and intravenous rehydration without forced

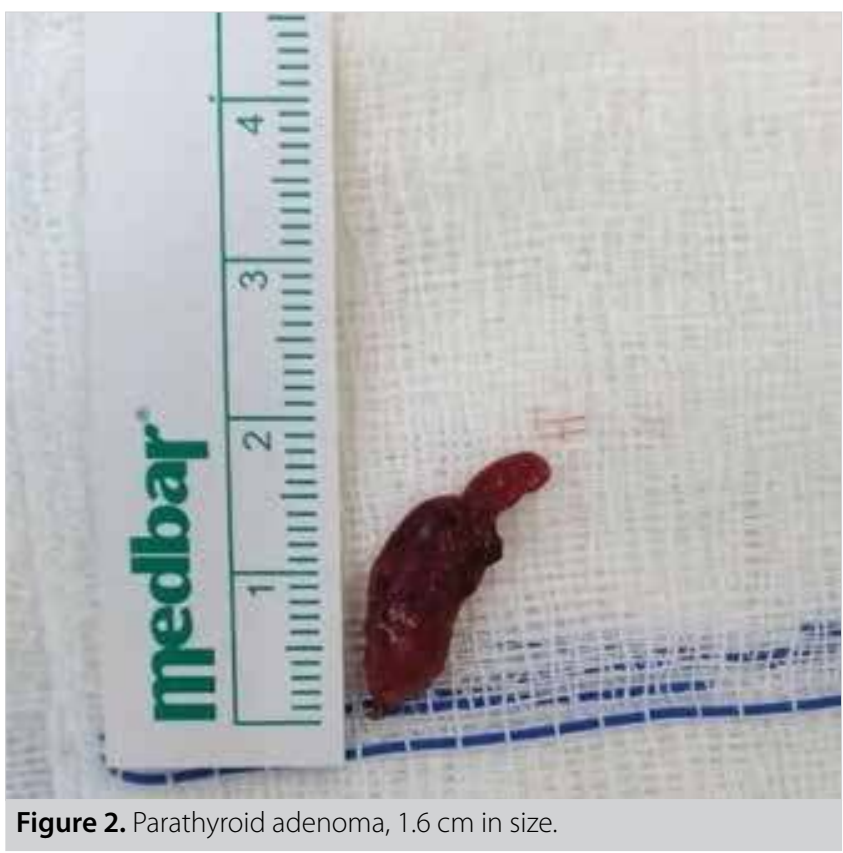

diuresis and an overnight fasting, the patient was operated under LMA, and intraoperative USG was used to determine the incision site. The patient also underwent FLA, and intraoperative PTH decreased sufficiently (from $274 \mathrm{pg} / \mathrm{mL}$ to $36 \mathrm{pg} / \mathrm{mL}$ ).

Postoperative obstetric USG confirmed presence of fetal cardiac activity. The patient had an uneventful recovery and was discharged on postoperative day 2 with normal levels of serum calcium and PTH. Histopathological examination revealed a solitary parathyroid adenoma (Figure 4). At the $37^{\text {th }}$ week of gestation, she delivered a healthy female infant with no evidence of complication related to hypercalcemia or LMA. 

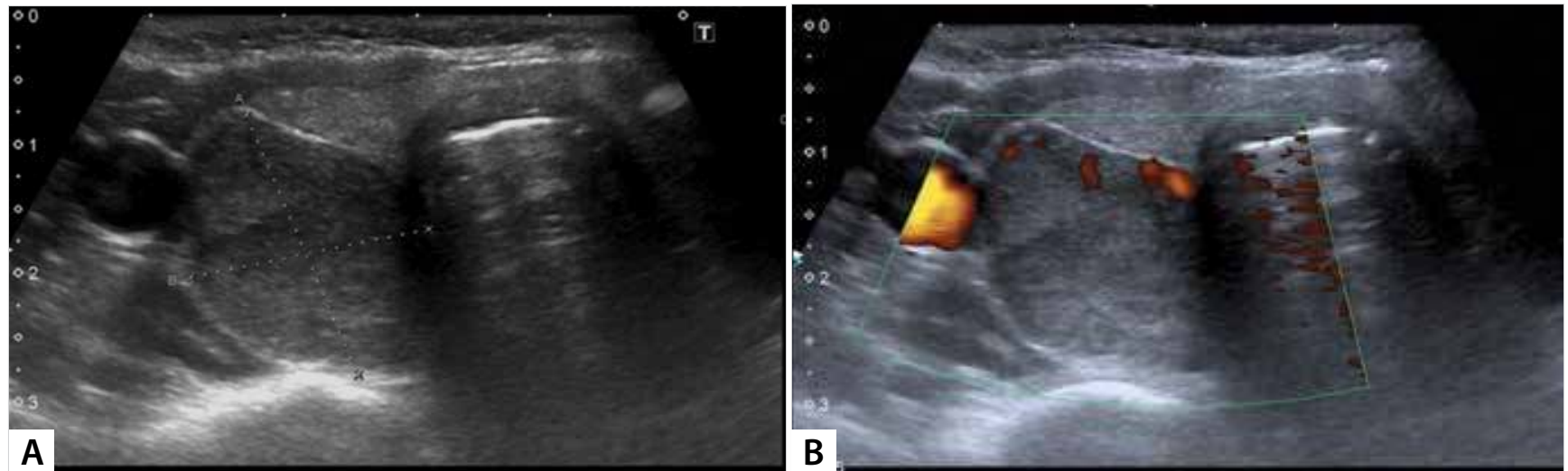

Figure 3. A hypoechoic well-circumscribed lesion $21 \times 18 \mathrm{~mm}$ in size in the right thyroid capsule was observed on ultrasound. It was noticeable that the lesion is slightly heterogeneous (A). Doppler ultrasound examination revealed peripheral vessel sign of the adenoma (B).

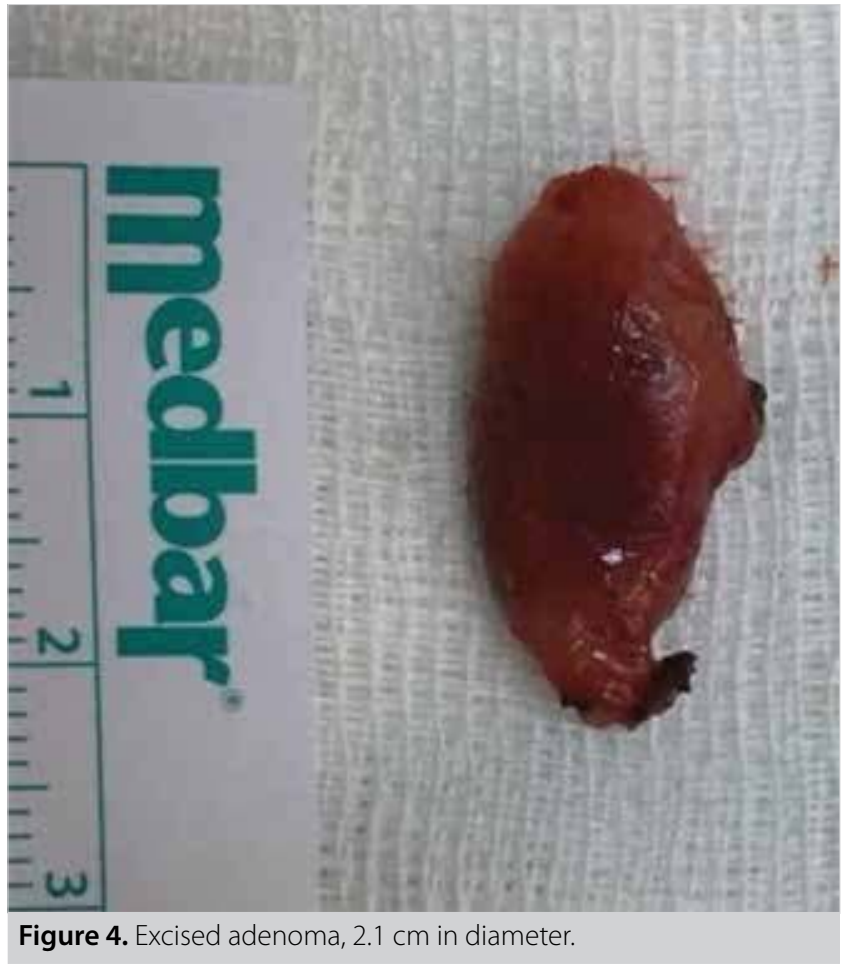

Written informed consents were obtained from the patients for publication of this case report and any accompanying images.

\section{DISCUSSION}

pHPT can be a serious, life threatening condition for both the fetus and the mother. If undiagnosed and untreated, it has been reported to lead to maternal complications which are hyperemesis, nephrolithiasis, maternal hypertension, preeclampsia, depression, constipation, bone fractures, pancreatitis, heart rhythm problems, and more common hypercalcemic crisis in almost 2/3 of the cases (5).

Fetal death, fetal growth retardation, preterm delivery and decreased birth weight are the most serious risks for the fetus and increase three to five times more in pregnant women with pHPT (6). In a study, thirty-two pregnant women diagnosed with pHPT had a history of miscarriage rate up to $50 \%$ in their previous pregnancy. This rate is six times more than accepted in the whole population (7). Postpartum neonatal tetany may occur in the first 2 weeks of delivery and affect approximately half of the children of those untreated pregnant women. Intrauterine parathyroid suppression is the main reason of neonatal tetany. In the literature, most of the patients recovered, while hypocalcemia remained permanent in some reported cases $(6,8)$.

Prompt diagnosis and treatment can prevent such complications for both the fetus and the pregnant women.

Diagnosis of pHPT is challenging in pregnancy. Approximately $80 \%$ of the cases are asymptomatic, while the most common symptoms are nausea, vomiting, polyuria, polydipsia, and cloudy vision in symptomatic patients. Many of these symptoms may erroneously be accepted as corollary of pregnancy (8). Physiologic changes in pregnancy such as hemodilution related hypoalbuminemia, calcium transfer to the fetus bone and increased renal clearance of calcium play a role on decreased calcium level of the mother. Pregnancy does not affect PTH level; but, clinicians should consider PHPT in the presence of an elevated PTH and serum calcium levels. One should consider the diagnosis of pHPT in pregnancy in the presence of an elevated ionized serum calcium and PTH levels in the absence of other causes of hypercalcemia.

USG of the neck is the first-line tool for preoperative localization of the diseased gland(s) in pregnancy since other methods such as $99 \mathrm{mTc}$-sestamibi and computed tomography carry the risk of ionizing radiation to the fetus. On the detection of parathyroid lesions, USG has a sensitivity of $65-75 \%$ and specificity of $90-94 \%$ in experienced hands and that ratio increases in the solitary adenoma cases (9). The most common cause of pHPT in pregnancy is solitary adenoma. PTH level assay in USG-guided aspirate of suspicious parathyroid adenoma has also been reported as an alternative method for diagnosis (2). 
Since pHPT during pregnancy is rare, the management is also challenging and no definite treatment guidelines have been established. Treatment should be individualized according to the severity of patients' complaints, the severity of hypercalcemia and the gestational age.

Hyperparathyroidism in the first trimester should be managed medically (10). A pregnant woman with mild hypercalcemia $(<11 \mathrm{mg} / \mathrm{dL})$ can also be managed medically.

Rehydration (oral/intravenous) with or without forced diuresis is the mainstay of initial management with close monitoring of the fetus and the mother. A few drugs (calcitonin, cinacalcet) are available for the treatment of PHPT in pregnancy but more evidence about their safety for fetus are needed. Bisphosphonates are contraindicated in pregnancy.

Surgery is the only curative treatment and is indicated when serum calcium levels are above $11 \mathrm{mg} / \mathrm{dL}$ or ionized calcium level exceeds $2.75 \mathrm{mmol} / \mathrm{L}$ during the second trimester. An image-guided, focused parathyroidectomy during the second trimester is the gold standard management of pPHT during pregnancy because organogenesis is complete and the risk of anesthesia-induced preterm delivery is very low (11).

The treatment of pHPT in the third trimester is also challenging, and risk and benefit of surgery should be assessed individually. Parathyroidectomy should be performed at any time regardless of the gestational age if the patient has severe hypercalcemia (12).

Since the most common cause of pHPT in pregnancy is adenoma, focused anterior or lateral approach is the preferred intervention due to shorter duration of operation, less risk for fetus, and lower complication risk $(2,6)$. We used ultrasonography to do the incision just over the adenoma for quicker access and intraoperative parathormone assay to confirm surgical success.

We preferred LMA for parathyroidectomy in pregnant women in the second trimester. LMA causes lesser sore throat, laryngospasm, and cough; and supplies rapid recovery as compared to endotracheal intubation anesthesia (13). Operation after an overnight fasting is sufficient to prevent regurgitation and aspiration which are possible complications of LMA in pregnancy. Lower abdominal pressure in the second trimester than in the third trimester also decreases the risk of LMA- related complications. To the best of our knowledge, parathyroidectomy under LMA in pregnancy has never been described before. We recommend the use of LMA in elective parathyroidectomy in the second trimester.

\section{CONCLUSION}

Although pHPT is rare in pregnancy, prompt diagnosis and management are mandatory. Focused parathyroidectomy with the use of intraoperative USG is a safe and effective treatment with confirmation by intraoperative PTH assay in the second trimester. In addition, LMA, which is a less invasive method than endotracheal intubation anesthesia, may be an alternative choice in pregnant patients undergoing focused parathyroidectomy.

Informed Consent: Written informed consent was obtained from all the patients who participated in this study.

Peer-review: Externally peer-reviewed.

Author Contributions: Concept - M.H., S.K.; Design - E.O.G., H.G.; Supervision - M.H., H.G.; Resource - S.G.H., E.O.G.; Materials - S.G.H., S.K.; Data Collection and/or Processing - T.A., S.K.; Analysis and/or Interpretation - H.G., F.T.; Literature Search - T.A., F.T.; Writing Manuscript - S.K., M.H.; Critical Reviews - M.H., H.G., F.T.

Conflict of Interest: The authors have no conflicts of interest to declare.

Financial Disclosure: The authors declared that this study has received no financial support.

\section{REFERENCES}

1. Kovacs CS. Calcium and bone metabolism disorders during pregnancy and lactation. Endocrinol Metab Clin North Am 2011; 40: 795-826. [CrossRef]

2. Pothiwala P, Levine SN. Parathyroid surgery in pregnancy: review of the literature and localization by aspiration for parathyroid hormone levels. J Perinatol 2009; 29: 779-84. [CrossRef]

3. Yilmaz BA, Altay M, Değertekin CK, Çimen AR, Iyidir ÖT, Biri A, et al. Hyperparathyroid crisis presenting with hyperemesis gravidarum. Arch Gynecol Obstet 2014; 290: 811-4. [CrossRef]

4. Abood A, Vestergaard P. Pregnancy outcomes in women with primary hyperparathyroidism. Eur J Endocrinol 2014; 171: 69-76. [CrossRef]

5. Dochez V, Ducarme G. Primary hyperparathyroidism during pregnancy. Arch Gynecol Obstet 2015; 291:259-63. [CrossRef]

6. Bendinelli C, Nebauer S, Quach T, Mcgrath S, Acharya S. Is minimally invasive parathyroid surgery an option for patients with gestational primary hyperparathyroidism? BMC Pregnancy Childbirth 2013; 13: 130. [CrossRef]

7. Norman J, Politz D, Politz L. Hyperparathyroidism during pregnancy and the effect of rising calcium on pregnancy loss: a call for earlier intervention. Clin Endocrinol (Oxf) 2009; 71: 104-9. [CrossRef]

8. Kokrdova Z. Pregnancy and primary hyperparathyroidism. J Obstet Gynaecol 2010; 30: 57-9. [CrossRef]

9. Vitetta GM, Neri P, Chiecchio A, Carriero A, Cirillo S, Mussetto AB, et al. Role of ultrasonography in the management of patients with primary hyperparathyroidism: retrospective comparison with technetium-99m sestamibi scintigraphy. J Ultrasound 2014; 17: 1-12. [CrossRef]

10. Schnatz PF, Curry SL. Primary hyperparathyroidism in pregnancy: evidence-based management. Obstet Gynecol Surv 2002; 57: 365-76. [CrossRef]

11. Kelly TR. Primary hyperparathyroidism during pregnancy. Surgery 1991; 110: 1028-33.

12. Diaz-Soto G, Linglart A, Sénat MV, Kamenicky P, Chanson P. Primary hyperparathyroidism in pregnancy. Endocrine 2013; 44: 591-7. [CrossRef]

13. Yu SH, Beirno OR. Laryngeal mask airways have a lower risk of airway complications compared with endotracheal intubation: A systematic review. J Oral Maxillofac Surg 2010; 68: 2359-76. [CrossRef] 


\title{
OLGU SERISI-ÖZET
}

Turk J Surg 2019; 35 (3): 231-235

\section{Gebelikte primer hiperparatiroidi için intraoperatif ultrasonografi kullanarak minimal invaziv paratiroidektomi: iki olgu sunumu}

\author{
Mehmet Haciyanlı ${ }^{1}$, Emine Özlem Gür ${ }^{1}$, Hüdai Genç ${ }^{1}$, Selda Gücek Haciyanlı ${ }^{1}$, Fatma Tatar ${ }^{1}$, Turan Acar ${ }^{1}$, Serkan Karaisli ${ }^{1}$
}

${ }^{1}$ İzmir Katip Çelebi Üniversitesi Atatürk Eğitim ve Araştırma Hastanesi, Genel Cerrahi Kliniği, İzmir, Türkiye

\section{ÖZET}

Gebelikte primer hiperparatiroidizm (pHPT) nadir görülen bir durumdur ve artmış maternal ve fetal mortalite ve morbidite ile ilişkilidir. Gebelikte pHPT'nin teşhisi zordur. Olguların yaklaşık \%80'i asemptomatiktir, semptomatik hastalarda ise en sık görülen semptomlar bulantı, kusma, poliüri, polidipsi ve bulanık görmedir. Gebelikte pHPT'nin en yaygın nedeni genel popülasyonda olduğu gibi adenom olduğu için; daha kısa operasyon süresi, fetus için daha az risk ve daha düşük komplikasyon riski nedeniyle odaklanmış anterior veya lateral yaklaşım önerilmektedir. Adenomun hemen üzerinde insizyon yapabilmak için intraoperatif ultrasonografi yapılması, adenomun daha hızı tespitini sağlar ve intraoperatif parathormon testi ile cerrahi tedavi doğrulanır. Laringeal maske anestezisi endotrakeal entübasyona göre daha az boğaz ağrısı, laringospazm ve öksürüğe neden olur ve hızlı iyileşme sağlar. Bu yazıda, gebeliğin ikinci trimesterinde pHPT tanısı konmuş ve intraoperatif ultrasonografi ve laringeal maske anestezisi altında minimal invaziv paratiroidektomi uygulanmış olan iki gebe hastanın tedavisi sunulmaktadır. Bildiğimiz kadarıyla, gebelikte laringeal maske anestezi altında paratiroidektomi daha önce tanımlanmamıştır.

Anahtar Kelimeler: Gebelik, gestasyonel hiperparatiroidi, intraoperatif ultrasonografi, laringeal maske anestezi, minimal invaziv paratiroidektomi

Doi: $10.5578 /$ turkjsurg.4330 